\title{
Karakteristik fisis bioplastik yang dibuat dari kombinasi pati tapioka dan kasein susu apkir
}

\section{Physical characteristics of bioplastic made from combination of tapioca starch and rejected milk casein}

\author{
Ariya Dwi Nugrahanto ${ }^{1}$, Asih Kurniawati², Yuny Erwanto ${ }^{1 *}$ \\ ${ }^{1}$ Jurusan Teknologi Hasil Ternak, Fakultas Peternakan, Universitas Gadjah Mada, J1. Fauna No. 1, Sleman 55281, Indonesia \\ ${ }^{2}$ Jurusan Nutrisi dan Makanan Ternak, Fakultas Peternakan, Universitas Gadjah Mada, Jl. Fauna No. 1, Sleman 55281, \\ Indonesia \\ *Penulis korespondensi. Telp. +628156878535 \\ E-mail: yunyer@ugm.ac.id
}

Diterima: 27 Oktober 2021

Direvisi: 16 Nopember 2021

Disetujui: 22 Nopember 2021

\begin{abstract}
This study aimed to develop bioplastic from a combination of tapioca starch and casein, as well as to determine the physical characteristics, such as thickness, density, light transmittance, and opacity. The composition of the bioplastic was made from two types of casein, namely commercial casein and rejected milk casein, with a ratio of tapioca starch and casein consisting of 4 treatment groups (4:0, 3:1, 2.5:1.5, 2:2). Each treatment was repeated 6 times. The physical characteristics data obtained were analyzed using a two-way ANOVA completely randomized design variance analysis. If there is a difference, it is continued with the Duncan multiple range test (DMRT). The results showed that the ratio of starch and casein had a very significant effect on all test parameters $(P<0.01)$. An increase in commercial casein (CC) and rejected milk casein (EMC) increased thickness and opacity, while density and light transmittance decreased. Based on the research, bioplastic can be made with a combination of different ratios of tapioca starch and casein types with the best result were at a ratio of 2:2 which produced a thickness of $0.29 \mathrm{~mm}$, light transmittance of $20.03 \%$, opacity of $2.51 \%$, while the density had the smallest value at $0.15 \mathrm{gr} / \mathrm{cm}^{3}$. In conclusion, rejected milk casein could be used as biomaterial to make bioplastic combined with tapioca starch.
\end{abstract}

Keywords: bioplastic, biopolymer, casein, rejected milk, tapioca.

\begin{abstract}
ABSTRAK
Penelitian ini bertujuan untuk mengembangkan bioplastik dari kombinasi pati tapioka dan kasein serta mengetahui karakteristik fisis, seperti ketebalan, densitas, transmisi cahaya, dan opasitas. Komposisi bioplastik dibuat dari dua jenis kasein, yaitu kasein komersial dan kasein susu afkir, dengan perbandingan pati tapioka dan kasein yang terdiri dari 4 kelompok perlakuan $(4: 0,3: 1,2,5: 1,5,2: 2)$. Setiap perlakuan diulang sebanyak 6 kali. Data karakteristik fisis, yang diperoleh, dianalisis menggunakan analisis varian rancangan acak lengkap two-way Anova. Jika terdapat perbedaan, dilanjutkan dengan uji Duncan multiple range test (DMRT). Hasil penelitian menunjukkan bahwa rasio pati dan kasein berpengaruh sangat nyata terhadap semua parameter uji $(\mathrm{P}<0,01)$. Peningkatan kasein komersial (KK) dan kasein susu apkir (KSA) meningkatkan ketebalan dan opasitas, sementara densitas dan transmisi cahaya menurun. Berdasarkan penelitian yang dilakukan, bioplastik dapat dibuat dengan kombinasi rasio pati tapioka dan jenis kasein yang berbeda dengan hasil terbaik pada rasio 2:2 yang menghasilkan ketebalan 0,29 mm, transmisi cahaya 20,03\%, opasitas 2,51\%, sementara pada densitas memiliki nilai terkecil 0,15 $\mathrm{gr} / \mathrm{cm}^{3}$. Kesimpulannya bahan kasein dari susu apkir masih bisa digunakan sebagai biomaterial untuk pembuatan bioplastik dikombinasikan dengan tepung tapioka.
\end{abstract}

Kata Kunci: bioplastik, biopolimer, kasein, susu apkir, tapioka. 


\section{PENDAHULUAN}

Produk susu sapi dan turunannya memiliki banyak penggemar di setiap segmen usia di masyarakat. Hal ini dibuktikan dengan konsumsi susu sapi segar di Indonesia per kapita tahun 2013 sampai 2017 mengalami kenaikan dari 0,104 menjadi $0,313 \mathrm{~L} /$ tahun, sementara produk susu sapi pabrikan dari 1,460 menjadi 3,546 L/ tahun, dan diprediksi meningkat setiap tahunnya (Ditjen PKH, 2019). Banyaknya permintaan akan produk susu sapi, mendorong peternak untuk menghasilkan susu yang lebih banyak untuk disetorkan ke koperasi maupun Industri Pengolahan Susu (IPS). Data menunjukkan produksi susu sapi di Indonesia pada tahun 2014 sampai 2019 mengalami kenaikan sebesar 24,44\% dari 800.749,00 ton menjadi 996.442,44 ton (BPS, 2019). Peningkatan permintaan dan konsumsi susu sapi segar, maupun susu sapi yang sudah diolah, secara alami juga akan meningkatkan potensi limbah dan produk yang tidak terpakai. Hal tersebut karena susu merupakan produk yang mudah rusak akibat aktivitas mikrobia dan kerusakan fisikokimia, mulai dari saat pemerahan sapi sampai pengolahan susu. Murti et al. (2012) melaporkan susu sapi pasteurisasi yang disimpan pada hari ke-0 sampai hari ke-16 menyebabkan penurunan kualitas fisis susu, khususnya parameter uji alkohol dari negatif menjadi positif, uji berat jenis dari 1,027 menjadi 1,026. Lebih lanjut dijelaskan bahwa hasil uji kimiawi menunjukkan penurunan kadar protein dari $19,14 \%$ menjadi $14,16 \%$, kadar lemak dari 3,4\% menjadi 3,3\%, serta asam lemak meningkat dari $0,51 \mathrm{~mL}$ menjadi $11,20 \mathrm{~mL}$. Susu yang mendekati masa apkir maupun diapkir karena kondisinya tidak layak konsumsi, biasanya tidak mendapat apresiasi baik dari konsumen maupun produsen di marketplace online maupun offline. Susu yang kualitasnya sudah menurun, bila tidak dikelola, akan menumpuk di tempat penyimpanan. Akibatnya akan berakhir menjadi limbah yang dapat mencemari lingkungan bila dibuang secara langsung. Susu sapi (whole milk) dan susu sapi pasteurisasi apkir sebenarnya masih memiliki potensi yang bisa dimanfaatkan, salah satunya adalah hidrokoloid yang berasal dari protein susu, yaitu kasein.

Kasein dapat diolah menjadi bioplastik dan turunannya seperti pelapis (coating), film, dan sheet yang bersifat edible maupun non-edible. Penelitian sebelumnya banyak memanfaatkan kasein komersial sebagai bioplastik. Chevalier et al. (2018) berhasil menemukan formulasi extrude sheet yang terbuat dari berbagai jenis kasein komersial (kasein renet, kasein acid, dan sodium kaseinat) dengan plasticizer gliserol. Durmaz dan Aytac (2019) berhasil menemukan formulasi film non-edible berbahan dasar kasein, polivinil alkohol (PVA), gliserol, dan air. Sabil et al. (2021) menemukan formulasi edible film berbahan dasar kasein denganberbagaikonsentrasi, air,dan gliserol.

Beberapa kelemahan ditemukan dalam bioplastik berbasis kasein, baik yang bersifat edible maupun non-edible. Timbulnya interaksi antara asam amino polar dan non-polar dalam struktur kasein membentuk matriks film yang kohesif dan cenderung mengalami penyusutan selama pengeringan (Xu \& Gowen, 2019) dan rekatnya kohesi antar protein yang kuat menyebabkan biopolimer berbasis kasein menjadi rapuh (Chen et al., 2019a). Timbulnya sifat rapuh dan retakan selama pengeringan berlangsung dapat menyebabkan produk yang dihasilkan memiliki sifat fisis maupun mekanis yang buruk dan terbatasnya penggunaan produk yang dihasilkan (Vieira et al., 2011). Pendapat tersebut diperkuat Lisitsyn et al. (2021), bahwa kasein yang hanya diplastisisasi tidak dapat memberikan kekuatan mekanis yang tinggi atau elastisitas yang baik dibandingkan dengan bahan polimer sintetik. Darni et al. (2018) menyatakan rendahnya nilai sifat mekanis pada film dengan disebabkan rendahnya nilai densitas pada film. Maruddin et al. (2017) menyatakan bahwa umumnya sifat khas film berbasis protein susu memiliki sifat tidak transparan dan tidak kompak.

Salah satu solusi untuk mendapatkan bioplastik yang tidak memiliki sifat rapuh, retak, bobot susut tinggi, densitas yang rendah, dan tidak transparan, yaitu dengan mengkombinasikan polimer kasein dengan polisakarida. Pengkombinasian ini didasari bahwa polisakarida merupakan bahan biodegradable yang memiliki sifat biokompatibilitas dan biostabilitas yang baik dengan biopolimer berbasis protein (Benbettaïeb et al., 2016). Beberapa penelitian telah berhasil menemukan bioplastik dengan kombinasi kasein dengan polisakarida dengan sifat edible dan nonedible. Saikia dan Badwaik (2018) telah berhasil menemukan formulasi pembuatan bioplastik berbahan dasar kasein, pektin, air, dan gliserol. Rai dan Poonia (2019) berhasil menemukan formulasi bioplastik berbahan dasar kasein, pati kacang, gliserol, dan air. Li et al. (2020) berhasil 
menemukan formulasi bioplastik berbahan dasar kasein, khitosan, gliserol, dan air. Ryder et al. (2020) telah berhasil menemukan formulasi hidrokoloid bersumber kasein dari limbah industri susu dan polisakarida, yaitu K-karagenan yang ditambah dengan air sebagai bioplastik.

Adanya kombinasi polisakarida, protein, dan plasticizer dapat memperbaiki sifat rapuh dan retak dengan cara meningkatkan viskoelastisitas dan ekstensibilitas (O'Chiu \& Vardhanabhuti, 2017; Suderman et al., 2018). Adanya penambahan polisakarida dan peningkatan gliserol dapat memperbaiki dan meningkatkan densitas bioplastik berbasis protein secara umum (Chevalier et al., 2018; Darni et al., 2018). Polisakarida yang melimpah di Indonesia salah satunya yaitu tapioka. Penelitian tapioka sebagai bioplastik sudah banyak dilakukan, salah satunya penelitian Nurhajati et al. (2019) yang menemukan bioplastik dengan sifat termoplastik dari tapioka, gliserol, air, dan dikatalis dengan asam asetat. Polimer tapioka, secara umum, memberikan sifat struktur yang kompak, tidak toksik, memiliki kapasitas filmogenik baik dalam membentuk bioplastik yang tidak berwarna dan tidak berasa (Hatmi et al., 2020; Mulyono et al., 2015). Adanya sifat pada polimer tapioka dapat mengatasi kelemahan struktur yang tidak kompak, mengatasi sifat tidak transparan pada bioplastik berbasis protein, khususnya kasein sehingga menjadi lebih kompak, aman, dan menarik. Kombinasi kasein dengan tapioka dengan rasio tapioka yang lebih banyak dari kasein telah berhasil meningkatkan kemampuan water holding capacity (WHC) dan kadar air gel yang difungsikan sebagai film edible sehingga dapat diasumsikan menghasilkan penyusutannya lebih rendah (Lindriati et al., 2014). Pendapat ini diperkuat hasil penelitian Martins et al. (2020), yaitu adanya kombinasi polisakarida dan protein dengan rasio polisakarida lebih banyak dari protein dapat meminimalkan bobot susut yang terjadi selama proses termal dengan pengeringan berlangsung. Adanya kombinasi kasein dan tapioka dapat meningkatkan viskositas yang berimplikasi pada meningkatnya ketebalan (Cortés-Rodríguez et al., 2020; Lindriati et al., 2014). Adanya kombinasi antara kasein dan tapioka dapat menjadi sarana untuk meminimalkan biaya produksi pembuatan bioplastik dan juga memungkinkan mengatasi kekurangan karakteristik bioplastik yang berasal hanya dari polisakarida ataupun protein. Penggunaan kasein dari susu sapi segar dan komersial sebagai bahan baku bioplastik menyebabkan meningkatnya biaya produksi sehingga bioplastik yang dihasilkan memiliki biaya relatif mahal. Selain itu penggunaan kasein akan bersaing sebagai bahan baku untuk pangan manusia. Penggunaan kasein dari susu apkir dapat menjadi jawaban dari masalah ini, karena susu apkir tidak akan menimbulkan biaya yang besar dan tidak bersaing sebagai sumber pangan.

Pembuatan bioplastik dari kombinasi pati tapioka dan kasein memungkinkan terbentuk karena adanya interaksi antara protein dan polisakarida yang berhasil membentuk ikatan bersama komponen lain. Bonnaillie et al. (2014) mengemukakan bahwa kasein memilki beberapa kelompok fungsional, termasuk $-\mathrm{NH}$, serta muatan $(+)$ dan $(-)$ yang tersusun dalam misel yang dapat berikatan pada gugus panjang serta lurus $-\mathrm{OH}$ dan -COO- pada polisakarida, gugus kecil pola $3-\mathrm{OH}$ pada gliserol dan $\mathrm{Ca}^{2+}$ yang memiliki dua molekul positif. Hasil penelitian Lindriati et al. (2017) menunjukkan bahwa interaksi kasein dan tapioka dalam matriks film edible ditandai dengan interaksi karbohidrat mendorong pembentukan ikatan hidrogen di situs peregangan $\mathrm{C}-\mathrm{OH}$ yang muncul pada $\mathrm{pH}$ 4,7 dan 9, serta pada berubahnya struktur sekunder protein. Ikatan tersebut terjadi akibat interaksi antara gugus hidroksil dan amin pada polisakarida dan kasein (Rai \& Poonia, 2019). Sifat interaksi non-kovalen, baik tarikmenarik atau tolak-menolak, termasuk gaya elektrostatik, hidrofobik, hidrogen, van der Waals, dan bahkan reaksi maillard. Interaksi tersebut dianggap sebagai perilaku antar-muka sistem protein-polisakarida-air, dan biasanya dijelaskan oleh aspek termodinamika yang mengarah ke salah satu dari tiga kemungkinan yaitu complexation, cosolubility, dan segregation (Wusigale et al., 2020). Pengembangan bioplastik dengan bahan kombinasi biokomposit tapioka dan kasein susu dengan bahan penunjang seperti gliserol, asam asetat, dan air menarik untuk dilakukan. Bioplastik yang dihasilkan dan karakternya dapat menjadi dasar pertimbangan peneliti selanjutnya bila ingin membuat bioplastik dengan tujuan edible maupun non-edible, bahkan diversifikasi produk yang lain sesuai kebutuhan konsumen. Oleh karena itu, penelitian ini dilakukan untuk mengetahui pengaruh kombinasi biopolimer pati dan jenis kasein yang berbeda terhadap kualitas sifat fisis bioplastik, seperti ketebalan, densitas, opasitas, dan transmisi cahaya. 


\section{BAHAN DAN METODE Bahan Penelitian}

Bahan yang digunakan dalam penelitian ini adalah susu pasteurisasi rendah lemak yang mendekati masa apkir merek Mataram Milk, tepung pati singkong merek Pak Tani, gliserol merek Bratachem, akuades, kasein komersial merek Sigma CAS kode CAS: 9000-71-9 (tecnical grade).

\section{Peralatan Penelitian}

Alat penunjang dalam penelitian ini gelas beker, kompor listrik, magnetic stirer, plastik wrap, aluminium foil, timbangan analitik, electric cream separator merek Taishi, spektrofotometer merek UV-1201v Shimadzu, digital thickness gauge, teflon dalam bentuk nampan.

\section{Metode Penelitian}

Perlakuan pada penelitian ini terdiri dari 2 perlakuan yang terdiri dari faktor perbedaan rasio pati dan kasein diperoleh dari pra-penelitian yang dilakukan sebelumnya, yaitu $4: 0 ; 3: 1 ; 2,5: 1,5$, dan 2:2 (b/b) dengan dua jenis kasein (kasein komersial dan kasein susu apkir). Penelitian ini menggunakan rancangan acak lengkap 2 faktor (two-way anova) $2 \times 4$ dengan 6 kali ulangan. Perbedaaan antar perlakuan diuji lanjut dengan uji Duncan's multiple range test (DMRT).

\section{Pembuatan Kasein dari Susu Apkir (KSA)}

Bahan yang digunakan adalah susu rendah lemak yang berumur 3 (tiga) hari mendekati apkir. Susu tersebut kemudian diisolasi kaseinnya mengikuti metode Sarode et al. (2016) dengan menambahkan $\mathrm{HCl}$ encer (10\%) pada suhu 35 ${ }^{\circ} \mathrm{C}$, pH 4,1 sampai 4,6 agar terjadi koagulasi. Presipitat kasein yang muncul dalam bentuk gumpalan kemudian disaring untuk dipisahkan dari cairan whey. Kasein dimasukan ke wadah kemudian direndam dengan larutan pencuci dan diaduk dengan ketentuan volume pencucian kasein harus sama dengan jumlah whey yang dihasilkan. Presipitat kasein selanjutnya dicuci dengan tiga tahap dengan durasi waktu kontak masing-masing 15 sampai 20 menit. Pencucian pertama dan kedua dilakukan pada suhu $35^{\circ} \mathrm{C}$ dengan akuades $\mathrm{pH}$ 4,6 dengan bantuan $\mathrm{HCl}$. Pencucian terakhir dengan akuades dilakukan pada suhu $32{ }^{\circ} \mathrm{C}$ sampai $40{ }^{\circ} \mathrm{C}$ pada $\mathrm{pH}$ netral.

Presipitat, yang dihasilkan, dilakukan pengepresan selama 12 sampai 15 jam dengan tekanan $34 \mathrm{~kg} . \mathrm{cm}^{-2}$ sampai terbentuk curd. Curd yang dihasilkan kemudian ditempatkan pada nampan secara rata dan dikeringkan pada suhu $52{ }^{\circ} \mathrm{C}$ sampai $57{ }^{\circ} \mathrm{C}$. Kasein, yang sudah kering, didiamkan selama 24 jam untuk menurunkan suhu. Selanjutnya, kasein digiling dalam keadaan dingin untuk mencegah kerusakan protein dan diayak untuk mendapatkan ukuran yang seragam. Kasein yang diperoleh disimpan dalam wadah tertutup (Sarode et al., 2016).

\section{Pembuatan Bioplastik}

Bioplastik dibuat dengan mengikuti bahan baku sebagaimana dilakukan oleh Rai dan Poonia (2019) dengan sedikit modifikasi dan dilakukan penambahan asam asetat sebagai katalis sesuai penelitian Nurhajati (2017). Pembuatan larutan sesuai metode Saikia dan Badwaik (2018) dengan sedikit modifikasi. Pembuatan larutan kasein diawali dengan menimbang kasein, yang berasal dari Kasein Komersial (KK) dan Kasein Susu Apkir (KSA), sesuai rasio (Tabel 1) di dalam 40 $\mathrm{mL}$ akuades yang ditambahkan $\mathrm{NaOH}$ sampai $\mathrm{pH}$ berkisar antara 7 sampai 8. Campurkan larutan kasein dengan pati sesuai rasio (Tabel 1). Ketika campuran larutan bersuhu $45^{\circ} \mathrm{C}$ ditambahkan 1,93 gr gliserol dan $15 \mathrm{~mL}$ akuades (Nuriyah et al., 2018). Campuran tersebut, bila sudah mencapai suhu $60{ }^{\circ} \mathrm{C}$, ditambahkan asam asetat $1,93 \mathrm{~mL}$, selanjutnya dipanaskan sampai suhu $85^{\circ} \mathrm{C}$ sampai terjadi gelatinasi (Pellá et al., 2020).

Pembuatan film plastik dilakukan dengan menuang sebanyak $55 \mathrm{~mL}$ larutan tersebut di dalam teflon berdiameter $13 \mathrm{~cm}$ dan dikeringkan pada oven $50{ }^{\circ} \mathrm{C}$ (Thakur et al., 2017) selama 20 jam. Pengelupasan dilakukan perlahan secara manual,

Tabel 1. Rasio pati dan kasein pada pembuatan bioplastik.

\begin{tabular}{lcccccccc}
\hline \multirow{2}{*}{$\begin{array}{c}\text { Jenis } \\
\text { kasein }\end{array}$} & \multicolumn{9}{c}{ 4:0 } & \multicolumn{9}{c}{ 3:1 } & \multicolumn{2}{c}{$2,5: 1,5$} & \multicolumn{2}{c}{$2: 2$} \\
\cline { 2 - 9 } & Pati & Kasein & Pati & Kasein & Pati & Kasein & Pati & Kasein \\
\hline KK & 4,12 & 0,00 & 3,09 & 1,03 & 2,58 & 1,54 & 2,06 & 2,06 \\
KSA & 4,12 & 0,00 & 3,09 & 1,03 & 2,58 & 1,54 & 2,06 & 2,06 \\
\hline
\end{tabular}


dan bioplastik yang diperoleh disimpan pada suhu kamar dalam plastik zip PET yang berisi silika gel untuk menjaga kelembaban. Hal yang sama dilakukan pada bioplastik dengan bahan dasar kasein komersial.

\section{Variabel}

Variabel yang diamati adalah ketebalan, densitas, transmisi cahaya, opasitas. Analisis yang dilakukan terhadap sampel bioplastik untuk kasein komersial maupun kasein susu apkir meliputi kualitas fisis. Analisis kualitas fisis terdiri dari ketebalan, yang dianalisis dengan metode ASTM (2013), kemudian densitas (Nurfauzi et al., 2018), opasitas (Apriliyani et al., 2020), dan transmisi cahaya (Socaciu et al., 2020).

\section{Analisis Data}

Data yang diperoleh dianalisis menggunakan analisis varian rancangan acak lengkap 2 arah (two-way anova) model tetap, karena tidak melihat interaksi (Rahmawati \& Erina, 2020). Jika terjadi perbedaan karena perlakuan maka dilanjutkan uji Duncan's multiple range test (DMRT) (Purnomo \& Syamsul, 2017). Perhitungan dilakukan menggunakan bantuan SPSS versi 16.0.

\section{HASIL DAN PEMBAHASAN Penampilan Bioplastik}

Hasil penelitian ditampilkan pada gambar 1 menunjukkan bentuk fisik bioplastik dengan rasio pati dan jenis kasein yang berbeda. Bioplastik tanpa kasein (Gambar 1A) memiliki karakteristik transparan bening, fleksibel, elastis. Sementara bioplastik dengan penambahan kasein terlihat cerah dan kaku. Seiring bertambahnya level kasein, warna yang dihasilkan semakin kekuningan. Penambahan jenis kasein komersial (KK) menghasilkan warna putih kekunigan agak cerah (Gambar 1B1-1D1) seiring bertambahnya level kasein. Sementara pada kasein susu apkir (KSA) menghasilkan warna cenderung putih kekuningan cerah (Gambar 1B2-1D2).

Permukaan luar bioplastik mulus, tanpa adanya pori-pori pada bagian luar, dan retakan pada kedua jenis bioplastik. Bioplastik, yang terbuat dari pati saja, jarang ditemukan gelembung. Sementara pada bioplastik dengan kasein, meski tidak selalu dalam jumlah banyak, pada setiap peningkatan level kasein pasti dijumpai gelembung udara, dari ukuran kecil sampai agak besar, baik yang terpisah maupun berdekatan. Kondisi kemungkinan disebabkan tidak homogennya kasein sehingga masihmemunculkanadanyagelembung. Bioplastik yang dihasilkan dari pati memiliki karakteristik lengket saat disimpan di plastik zip, sementara bioplastik dengan kombinasi pati dan kasein, seiring bertambahnya kasein dalam campuran, semakin tidak lengket. Menurut Saikia dan Badwik (2018), bioplastik yang terbuat dari kombinasi pektin dan kasein lebih buram, serta tidak lebih homogen, yang ditandai dengan perubahan fase antara komponen daripada pektin saja. Hasil penelitian Ryder et al. (2020) menggunakan kasein apkir dan K-karagenan menghasilkan bioplastik yang kohesif dengan permukaan yang halus. Berkurangnya komponen polisakarida menyebabkan bioplastik menjadi rapuh dan tidak fleksibel. Visualisasi dengan SEM dalam penelitian Ryder et al. (2020) menunjukan semakin banyak komponen kasein dalam bioplastik menghasilkan struktur yang tidak homogen dan berpori, sehingga penampilan fisik bioplastik dipengaruhi oleh jenis bahan baku dan rasio protein dan polisakarida.
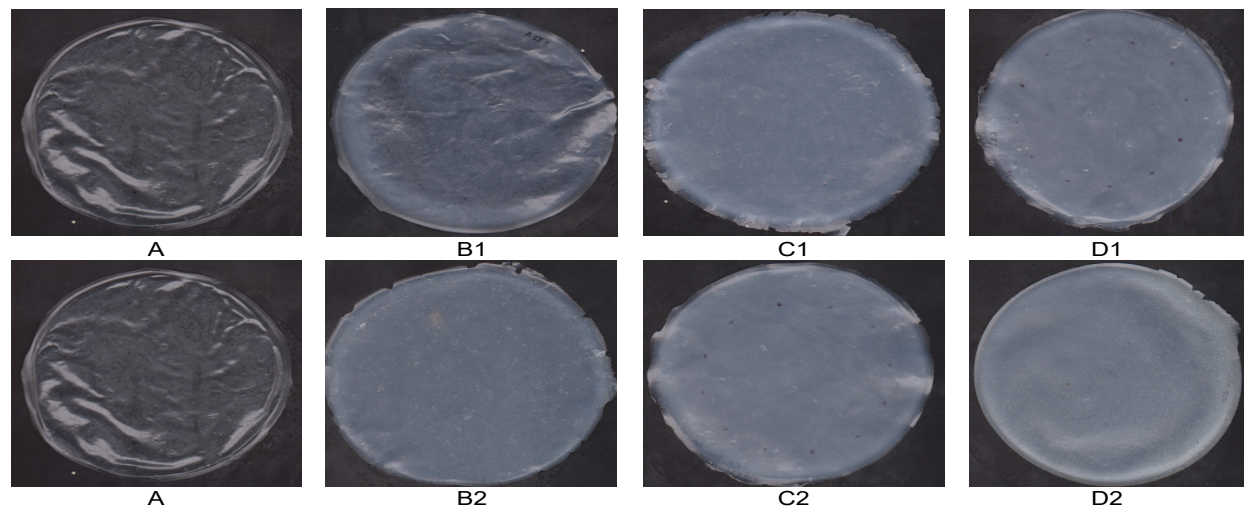

Gambar 1. Penampakan fisik bioplastik dengan rasio pati dan kasein 4:0 (A), 3:1 (B), 2,5:1,5 (C), 2:2 (D). 
Tabel 2. Ketebalan bioplastik dengan perbedaan rasio pati dan kasein.

\begin{tabular}{cccccc}
\hline \multirow{2}{*}{ Jenis kasein } & \multicolumn{4}{c}{ Ketebalan $(\mathrm{mm})$} & \multirow{2}{*}{ Rerata } \\
\cline { 2 - 5 } & $4: 0$ & $3: 1$ & $2,5: 1,5$ & $2: 2$ & \\
\hline KK & $0,23 \pm 0,01$ & $0,26 \pm 0,01$ & $0,28 \pm 0,02$ & $0,29 \pm 0,01$ & $0,27 \pm 0,03^{\mathrm{y}}$ \\
KSA & $0,24 \pm 0,01$ & $0,24 \pm 0,01$ & $0,26 \pm 0,01$ & $0,29 \pm 0,00$ & $0,26 \pm 0,02^{\mathrm{x}}$ \\
\hline Rerata & $0,24 \pm 0,01^{\mathrm{a}}$ & $0,25 \pm 0,02^{\mathrm{b}}$ & $0,27 \pm 0,02^{\mathrm{c}}$ & $0,29 \pm 0,01^{\mathrm{d}}$ & $0,26 \pm 0,02$ \\
\hline
\end{tabular}

Superskrip yang berbeda pada baris rerata menunjukkan perbedaan yang nyata $(\mathrm{P}<0,01)$

\section{Ketebalan}

Data hasil pengujian ketebalan disajikan pada Tabel 2. Hasil analisis varian menunjukkan bahwa ketebalan bioplastik yang dihasilkan meningkat dengan bertambahnya rasio kedua jenis kasein. Peningkatan ketebalan dengan meningkatnya kandungan kasein dalam bahan kemungkinan disebabkan oleh mikrostruktur kasein yang masih ada spase diantar molekul sehingga menyebabkan ketebalan meningkat. Berdasarkan uji statistik menggunakan DMRT pada taraf signifikan 0,01 menunjukkan ketebalan masing-masing perlakuan berbeda sangat nyata $(\mathrm{P}<0,01)$. Jenis kasein berpengaruh sangat nyata $(\mathrm{P}<0,01)$ pada ketebalan bioplastik yang dihasilkan, namun kasein KK secara rerata lebih tinggi dari pada KSA sebagaimana disajikan pada Tabel 2.

Hasil penelitian yang diperoleh (Tabel 2) sesuai dengan penelitian yang dilakukan Sabil et al. (2021), dimana seiring bertambahnya kasein menunjukkan ketebalan film semakin meningkat. Fakhouri et al. (2015) menggunakan bahan gelatin dan berbagai jenis pati dengan rasio pati dan gelatin yang berbeda $(4: 1,1: 1$, dan 1:4) serta jenis plasticizer yang berbeda menunjukkan kenaikan ketebalan film, yaitu berkisar antara $0,039 \mathrm{~mm}$ sampai 0,104 mm. Pellá et al. (2020), yang dalam penelitiannya menggunakan kombinasi bahan baku tapioka, gelatin, dan kasein, menunjukkan bahwa kenaikan ketebalan pada porsi kasein, yang lebih banyak, dari 0,77 menjadi $0,85 \mathrm{~mm}$. Hasil penelitian Cortés-Rodríguez et al. (2020) menunjukkan bahwa film dengan kombinasi antara protein dan polisakarida meningkatkan ketebalan film, yang terdiri dari polisakarida saja. Cortés-Rodríguez et al. (2020) berpendapat bahwa adanya perbedaan ketebalan film, yang hanya terdiri pati saja, dengan yang dikombinasi pati dan whey, berbeda karena dipengaruh laju pengeringan yang berbeda pada biokomposit, interaksi gugus hidrofilik bahan baku pada formulasi film, dan karena distribusi padatan yang tidak homogen per $\mathrm{cm}^{2}$ pada permukaan film selama pengeringan. Skurtys et al. (2011) menyatakan semakin tebal bioplastik dalam keadaan normal (tidak memiliki porisitas dan bersifat higroskopis), berimplikasi semakin baiknya kemampuannya dalam menurunkan nilai pertukaran gas seperti $\mathrm{O}_{2}$ dan $\mathrm{CO}_{2}$. JSA (1975) mempublikasikan bahwa film plastik untuk kemasan makanan mensyaratkan kemasan memiliki ketebalan maksimal 0,25 mm, sehingga bioplastik yang memenuhi syarat dalam penelitian ini adalah 4:0 dan 3:1. Bioplastik yang dihasilkan termasuk kategori thin plastic sheeting, yaitu thin sheeting dan film karena menghasilkan ketebalan kurang dari $1 \mathrm{~mm}$ (ASTM D6988-13). Perbandingan antara hasil yang diperoleh dengan literatur yang ada menunjukkan hasil penelitian ini masih dalam kisaran normal untuk rasio 4:0 dan 3:1. Berdasarkan hasil, yang diperoleh, diketahui bahwa yang mempengaruhi nilai ketebalan adalah komposisi bahan baku dan interaksi antar bahan baku dengan penunjang seperti dengan air, gliserol, asam, dan basa (basa pelarut kasein seperti $\mathrm{NaOH}$ dan asam yang digunakan untuk katalis seperti asam asetat) selama proses pencampuran dan proses termal berlangsung di oven.

\section{Densitas Bioplastik}

Hasil rerata densitas bioplastik yang dihasilkan sebagaimana disajikan pada Tabel 3 menunjukkan bahwa semakin tinggi rasio kasein dan penurunan rasio pati menyebabkan densitas bioplastik turun pada kedua jenis kasein. Berdasarkan uji statistik menggunakan DMRT pada taraf signifikan 0,01 menunjukkan densitas masing-masing perlakuan berbeda sangat nyata $(P<0,01)$. Jenis kasein berpengaruh sangat nyata $(\mathrm{P}<0,01)$ pada densitas bioplastik yang dihasilkan, namun kasein KSA secara rerata lebih tinggi daripada KK.

Densitas merupakan massa persatuan volume. Densitas sangat penting karena menunjukkan kerapatan antar komponen penyusun bioplastik. Seiring bertambahnya protein, densitas bioplastik 
Tabel 3. Densitas bioplastik dengan perbedaan rasio pati dan kasein.

\begin{tabular}{cccccc}
\hline \multirow{2}{*}{ Jenis kasein } & \multicolumn{4}{c}{ Densitas $\left(\mathrm{gr} / \mathrm{cm}^{3}\right)$} & \multirow{2}{*}{ Rerata } \\
\cline { 2 - 5 } & $4: 0$ & $3: 1$ & $2,5: 1,5$ & $2: 2$ & \\
\hline KK & $0,18 \pm 0,00$ & $0,16 \pm 0,00$ & $0,15 \pm 0,01$ & $0,15 \pm 0,01$ & $0,16 \pm 0,01^{\mathrm{x}}$ \\
KSA & $0,17 \pm 0,00$ & $0,17 \pm 0,00$ & $0,17 \pm 0,01$ & $0,15 \pm 0,00$ & $0,17 \pm 0,01^{\mathrm{y}}$ \\
\hline Rerata & $0,17 \pm 0,00^{\mathrm{a}}$ & $0,16 \pm 0,01^{\mathrm{b}}$ & $0,16 \pm 0,01^{\mathrm{b}}$ & $0,15 \pm 0,01^{\mathrm{c}}$ & $0,16 \pm 0,01$ \\
\hline
\end{tabular}

Superskrip yang berbeda pada baris rerata menunjukkan perbedaan yang nyata $(\mathrm{P}<0,01)$.

menjadi turun karena nilai densitas bahan baku yang berbeda. Nilai densitas tapioka lebih besar daripada kasein, meski dalam jumlah total padatan yang sama. Densitas tepung tapioka 1,335 sampai $1,352 \mathrm{~g} / \mathrm{cm}^{3}$ (Romuli et al., 2017). Kasein komersial dengan jenis acid casein CAS kode CAS: 900071-9 memiliki densitas $1,25 \mathrm{gr} / \mathrm{cm}^{3}$, sementara misel kasein memiliki kisaran densitas 1,063 g/ $\mathrm{cm}^{3}$ (Broyard \& Gaucheron, 2015). Hal ini sesuai dengan rerata nilai densitas bioplastik (Tabel 3), dimana rasio pati dan kasein 4:0 lebih besar daripada bioplastik dengan rasio 3:1 sampai 2:2. Asmitara dan Darni (2016), yang menggunakan bahan gelatin dan rumput laut, menunjukkan semakin banyak protein menghasilkan densitas yang semakin kecil, rasio pati dan gelatin berturutturut dari yang tertinggi ke terendah yaitu 80:20, 70:30, 60:40, dan 50:50 dengan nilai kisaran densitas yang dihasilkan dalam penelitian ini yaitu 0,8 sampai $1,2 \mathrm{~g} / \mathrm{cm}^{3}$. Penelitian yang dilakukan oleh Darni et al. (2018) menggunakan bahan pati sorgum dan gelatin menunjukkan hasil yang sama dengan nilai densitas berkisar 0,152 sampai $0,224 \mathrm{gr} / \mathrm{cm}^{3}$. Hasil penelitian Darni et al. (2018) menunjukkan bahwa semakin turun kandungan pati dan naiknya protein menyebabkan turunnya densitas, danperubahan ini dapat disebabkankarena beberapa faktor, yaitu faktor rasio pati dan protein, serta kecepatan pengadukan. Hasil penelitian ini (Tabel 3) menunjukkan fenomena nilai densitas KK maupun KSA sama dan pada bioplastik KSA $0 \mathrm{~s} / \mathrm{d} 1,5$ densitasnya tidak berbeda. Hasil ini diduga dipengaruhi oleh jumlah gelembung yang ada pada bioplastik. Adanya gelembung yang terbentuk selama proses pencampuran dan pengadukan yang akhirnya terperangkap dalam bioplastik, yang dihasilkan, menyebabkan tekstur bioplastik menjadi berongga. Semakin banyak rongga yang terbentuk pada bioplastik mengisyaratkan bioplastik yang dihasilkan memiliki porositas yang buruk sehingga secara umum pada perbandingan 4:0 ke 2:2 menyebabkan penurunan. Chevalier et al. (2018) menyatakan nilai densitas yang rendah dan adanya porositas yang tinggi pada bioplastik yang terbuat dari acid casein dapat diatasi dengan menambahkan gliserol dengan rasio lebih banyak. Perbandingan antara hasil yang diperoleh (Tabel 3) dengan literatur yang ada menunjukkan hasil densitas dan tren penurunan densitas seiring berkurangnya rasio polisakarida dan meningkatnya protein dalam penelitian ini masih dalam kisaran hasil peneliti lain. Berdasarkan hasil yang diperoleh diketahui bahwa yang mempengaruhi nilai densitas adalah nilai densitas bahan baku, kecepatan pengadukan, serta rasio antara polisakarida dan protein.

\section{Transmisi Cahaya}

Hasil rerata transmisi cahaya bioplastik yang dihasilkan (Tabel 4) menunjukkan bahwa semakin tinggi rasio kasein dan penurunan rasio pati menyebabkan penurunan transmisi cahaya untuk kedua jenis kasein. Berdasarkan uji statistik menggunakan DMRT pada taraf signifikan 0,01 menunjukkan transmisi cahaya masing-masing perlakuan berbeda sangat nyata

Tabel 4. Transmisi cahaya bioplastik dengan perbedaan rasio pati dan kasein.

\begin{tabular}{lccccc}
\hline \multirow{2}{*}{ Jenis kasein } & \multicolumn{4}{c}{ Transmisi cahaya (\%) } & \multirow{2}{*}{ Rerata ${ }^{\text {ns }}$} \\
\cline { 2 - 5 } & $4: 0$ & $3: 1$ & $2,5: 1,5$ & $2: 2$ & \\
\hline KK & $56,95 \pm 2,6$ & $53,85 \pm 1,18$ & $30,46 \pm 1,89$ & $29,19 \pm 2,46$ & $42,60 \pm 13,27^{\mathrm{y}}$ \\
KSA & $56,00 \pm 3,35$ & $18,53 \pm 0,74$ & $19,40 \pm 2,15$ & $10,87 \pm 1,18$ & $26,20 \pm 18,01^{\mathrm{x}}$ \\
\hline Rerata & $56,47 \pm 2,91^{\mathrm{d}}$ & $36,19 \pm 18,47^{\mathrm{c}}$ & $24,93 \pm 6,09^{\mathrm{b}}$ & $20,02 \pm 9,73^{\mathrm{a}}$ & $34,40 \pm 17,71$ \\
\hline
\end{tabular}

Superskrip yang berbeda pada baris rerata menunjukkan perbedaan yang nyata $(\mathrm{P}<0,01)$. 
$(\mathrm{P}<0,01)$. Jenis kasein berpengaruh sangat nyata $(\mathrm{P}<0,01)$ pada transmisi cahaya namun secara rerata KK lebih tinggi daripada KSA.

Bioplastik yang difungsikan sebagai kemasan, baik edible maupun non-edible, harus memiliki prinsip dasar, yaitu dapat melindungi produk dari paparan sinar (Sucipta et al., 2017). Berdasarkan prinsip dasar tersebut, nilai transmisi cahaya yang semakin rendah menunjukkan kemampuan melindungi produk semakin baik, karena cahaya dapat merusak komponen bahan yang dikemas. Contohnya kasus rusaknya flavor akibat sinar matahari sehingga menimbulkan bau terbakar pada susu. Yuwanti et al. (2012) menyatakan timbulnya flavor terbakar dari susu terjadi akibat susu teroksidasi karena adanya foto-oksidasi yang melibatkan oksigen singlet. Energi dari cahaya diabsorbsi oleh riboflavin, kemudian ditransfer ke oksigen triplet (oksigen yang ada di atmosfer) dan menghasilkan oksigen singlet. Oksigen singlet mengoksidasi metionin pada susu menjadi dimetil disulfida.

Socaciu et al. (2020) menggunakan whey protein isolate (WPI) dan pemberian minyak esensial dari tanaman tarragon menyebabkan warna pada bioplastik semakin tidak jernih karena adanya perlakuan pemanasan yang menyebabkan laju transmisi cahaya menurun. Lebih lanjut, kisaran nilai transmisi cahaya yaitu 6,29\% sampai $65,66 \%$. Material termosplastik yang diteliti oleh Chen et al. (2019b) dikategorikan memiliki sifat optik yang baik sebagai air filter karena memiliki transparansi $\sim 60 \%$, yang mengisyaratkan pada transmisi cahaya yang cukup tinggi, dan dikatakan oleh Xiao et al. (2021) transparan bila nilai transmisi cahaya lebih dari 90\%. Laju transmisi cahaya pada bioplastik yang dibawah 90\% termasuk kategori semi transparan (Socaciu et al., 2020). Diduga, dalam penelitian ini, yang menyebabkan transmisi cahaya turun adalah kontribusi warna dari bahan baku sehingga menyebabkan bioplastik yang dihasilkan menjadi semi transparan dan meningkatnya opasitas. Warna yang dihasilkan bioplastik dalam penelitian ini adalah warna putih agak kekuningan cerah pada bioplastik KK hingga putih kekuningan keruh cerah pada bioplastik KSA. Warna yang timbul pada bioplastik disebabkan dari warna bahan bakunya. Sifat bening muncul dari pati (Hatmi et al., 2020; Alcázar-Alay \& Meireles, 2015). Warna putih salju berasal dari kasein, sementara kuning berasal dari karoten (Diastari \& Agustina, 2013). Perbandingan antara hasil yang diperoleh dan literatur yang ada menunjukkan nilai transmisi cahaya dalam kisaran normal dan tergolong semi transparan.

\section{Opasitas Bioplastik}

Hasilrerataopasitasbioplastik,yangdihasilkan, disajikan pada Tabel 5, dan menunjukkan bahwa semakin tinggi rasio kasein dan penurunan rasio pati menyebabkan kenaikan opasitas untuk kedua jenis kasein. Berdasarkan uji statistikmenggunakan DMRT pada taraf signifikan 0,01 menunjukkan bahwa opasitas setiap perlakuan berbeda sangat nyata $(\mathrm{P}<0,01)$. Jenis kasein berpengaruh sangat nyata $(\mathrm{P}<0,01)$ pada opasitas bioplastik namun kasein KSA secara rerata lebih tinggi dari pada KK.

Opasitas memiliki peran penting dalam proses filter cahaya sebelum mengenai suatu produk. Semakin rendah nilai opasitas, maka semakin tinggi nilai transparansinya, dan semakin tinggi laju transmisi cahayanya. Bioplastik yang hanya terbuat dari pati (4:0) memiliki sifat lebih jernih dan masih memiliki nilai opasitas karena proses gelatinasi. Shintya dan Enceng (2018) menyatakan bahwa selama gelatinasi, suspensi pati yang keruh, seperti susu, mulai berubah menjadi jernih pada suhu tertentu. Hal tersebut biasanya diikuti oleh pembengkakan granula pati. Pembengkakan menimbulkan sifat birefigent granula pati (sifat memantulkan cahaya) menjadi hilang setelah pecah dan kontak dengan air panas, dan tidak dapat kembali lagi atau yang disebut

Tabel 5. Opasitas bioplastik dengan perbedaan rasio pati dan kasein.

\begin{tabular}{cccccc}
\hline \multirow{2}{*}{ Jenis kasein } & \multicolumn{4}{c}{ Opasitas (\%) } & \multirow{2}{*}{ Rerata } \\
\cline { 2 - 5 } & $4: 0$ & $3: 1$ & $2,5: 1,5$ & $2: 2$ & \\
\hline KK & $0,92 \pm 0,08$ & $1,16 \pm 0,05$ & $1,61 \pm 0,16$ & $1,67 \pm 0,08$ & $1,34 \pm 0,33^{\mathrm{x}}$ \\
KSA & $0,94 \pm 0,10$ & $2,68 \pm 0,09$ & $2,83 \pm 0,01$ & $3,35 \pm 0,17$ & $2,45 \pm 0,93^{\mathrm{y}}$ \\
\hline Rerata & $0,93 \pm 0,09^{\mathrm{a}}$ & $1,92 \pm 0,80^{\mathrm{b}}$ & $2,22 \pm 0,65^{\mathrm{c}}$ & $2,51 \pm 0,89^{\mathrm{d}}$ & $1,89 \pm 0,89$ \\
\hline
\end{tabular}

Superskrip yang berbeda pada baris rerata menunjukkan perbedaan yang nyata $(\mathrm{P}<0,01)$. 
Birefigent End Point Temperarutre (Alcázar-Alay \& Meireles, 2015). Hal ini diperkuat pendapat Warkoyo et al. (2014), bahwa semakin tinggi kadar pati akan menyebabkan plastik lebih bening dan meningkatkan derajat kejernihannya. Penambahan pati yang semakin banyak, menyebabkan peluang untuk terjadinya proses gelatinasi semakin besar, yang mengakibatkan kejernihan film semakin bertambah, dan penambahan senyawa kimia, seperti kalium sorbat, menyebabkan opasitasnya naik. Apriliyani et al. (2020) menyatakan semakin tinggi kasein dan berkurangnya kitosan dalam rasio dapat meningkatkan opasitas. Nilai opasitas dalam penelitian ini berkisar $0,078 \%$ sampai $0,790 \%$. Riquelme et al. (2015) menyatakan bahwa reaksi maillard berkontribusi pada terbentuknya warna coklat, dan tingkat kecoklatannya meningkat seiring waktu pemanasan yang digunakan, dan bersama hal tersebut opasitas film juga meningkat. Berdasarkan hasil pengukuran transmisi cahaya (Tabel 4) dan opasitas (Tabel 5), diketahui bahwa faktor yang menyebabkan kualitas bioplastik berdasarkan sifat optik, yaitu adanya senyawa kimia, reaksi maillard, penambahan, dan warna asal bahan baku.

\section{KESIMPULAN}

Berdasarkan penelitian yang dilakukan, diketahui bahwa kasein dari susu apkir dapat digunakan sebagai bahan baku bioplastik. Bioplastik terbaik terdapat pada rasio kombinasi pati dan kasein 2:2 untuk semua jenis kasein, baik kasein komersial (KK) maupun kasein susu apkir (KSA). Hal ini ditinjau dari penampilan bioplastik yang ditunjukan pada rasio 2:2, khususnya pada warna yang dihasilkan sehingga menyebabkan nila transmisi cahaya pada KK $29,19 \%$ dan KSA $10,87 \%$, serta nilai opasitas untuk KK 1,67\% dan KSA 3,35\%. Nilai ketebalan dan densitas terbaik terdapat pada rasio 4:0 (tanpa kasein) 0,24 mm dan $0,16 \mathrm{gr} / \mathrm{cm}^{3}$ dan rasio $3: 1$ (dengan kasein) 0,25 $\mathrm{mm}$ dan $0,17 \mathrm{gr} / \mathrm{cm}^{3}$.

\section{UCAPAN TERIMA KASIH}

Terima kasih disampaikan pada Fakultas Peternakan Universitas Gadjah Mada yang telah memberikan bantuan dana hibah penelitian progam pasca dengan SK 2369/J01.1.25/PASCA/2020. Terima kasihjuga kepada UMKM Susu Pasteurisasi Mataram Milk Yogyakarta yang telah memberikan kesempatan untuk melaksanakan pengambilan data. Terima kasih juga kepada Rumah Ganesha yang telah memberikan bantuan pendidikan.

\section{DAFTAR PUSTAKA}

Alcázar-Alay, S. C., \& Meireles, M. A. A. (2015). Physicochemical properties, modifications and applications of starches from different botanical sources. Food Science and Technology, 35(2), 215236. https://doi.org/10.1590/1678-457X.6749

Asmitara, R., \& Darni, Y. (2016). Aplikasi edible film berbasis Eucheuma cottoni-gelatin pada buahbuahan. In J. Agustian, E. Azwar, D. Lesmana, Azhar, I. M. Gandidi, T. Suhartati, R. H. Ismono, H. Insan, F. E. Prasmatiwi, Subeki, Sutikno, T. Susanto, Susilawati (Eds.), Peran Teknologi dan Inovasi untuk Pengembangan Industri Berbasis Sumber Daya Alam Lokal Secara Terpadu (pp. 40-43). Bandar Lampung, Indonesia: Balai Riset dan Standardisasi Industri Bandar Lampung.

Apriliyani, M. W., Purwadi, Manab, A., W. Apriliyanti, M. W., \& Ikhwan, A. D. (2020). Characteristics of moisture content, swelling, opacity and transparency with addition chitosan as edible films/coating base on casein. Advance Journal of Food Science and Technology, 18(1), 9-14. https://doi.org/10.19026/ajfst.18.6041

ASTM (American Society for Testing and Materials). (2013). ASTM D6988-13 Standard guide for determination of thickness of plastic film test specimens. Pennsylvania, USA: ASTM. https:// doi.org/10.1520/D6988-13

BPS (Badan Pusat Statistik). (2019). Produksi susu segar menurut provinsi (ton) 2009-2019. https:// www.bps.go.id/linkTableDinamis/view/id/1083, diakses 25 Oktober 2021.

Benbettaïeb, N., Gay, J., Karbowiak, T., \& Debeaufort, F. (2016). Tuning the functional properties of polysaccharide-protein bio-based edible films by chemical, enzymatic, and physical crosslinking. Comprehensive Reviews in Food Science and Food Safety, 15(4), 739-752. https://doi. org/10.1111/1541-4337.12210

Bonnaillie, L. M., Zhang, H., Akkurt, S., Yam, K. L., \& Tomasula, P. M. (2014). Casein films: The effects of formulation, environmental conditions and the addition of citric pectin on the structure and mechanical properties. Polymers, 6(7), 2018 2036. https://doi.org/10.3390/polym6072018

Broyard, C., \& Gaucheron, F. (2015). Modifications of structures and functions of caseins: A scientific and technological challenge. Dairy Science \& Technology, 95, 831-862. https://doi.org/10.1007/ s13594-015-0220-y

Chen, H., Wang, J., Cheng, Y., Wang, C., Liu, H., Bian, H., Pan, Y., Sun, J., \& Han, W. (2019a). Application of protein-based films and coatings for food packaging: A review. Polymers, 11(12), 2039. https://doi.org/10.3390/polym11122039 
Chen, R., Zhang, X., Wang, P., Xie, K., Jian, J., Zhang, Y., Zhang, J., Yuan, Y., Na, P., Yi, M., \& Xu, J. (2019b). Transparent thermoplastic polyurethane air filters for efficient electrostatic capture of particulate matter pollutants. Nanotechnology, 30, 015703. https://doi.org/10.1088/1361-6528/ aae611

Chevalier, E., Assezat, G., Prochazka, F., \& Oulahal, N. (2018). Development and characterization of a novel edible extruded sheet based on different casein sources and influence of the glycerol concentration. Food Hydrocolloids, 75, 182-191. https://doi.org/10.1016/j.foodhyd.2017.08.028

Cortés-Rodríguez, M., Villegas-Yépez, C., Gil González, J. H., Rodríguez, P. E., \& Ortega-Toro, R. (2020). Development and evaluation of edible films based on cassava starch, whey protein, and bees wax. Heliyon, 6(9), e04884. https://doi. org/10.1016/j.heliyon.2020.e04884

Darni, Y., Lismeri, L., Hanif, M., \& Putra, N. (2018). Pengaruh bilangan Reynold pada sintesis bioplastik berbasis pati sorgum dan gelatin. Prosiding Seminar Nasional Kulit, Karet, dan Plastik, 7(1), 55-68.

Diastari, I. G. A. F., \& Agustina, K. K. (2013). Uji organoleptik dan tingkat keasaman susu sapi kemasan yang dijual di pasar tradisional Kota Denpasar. Indonesia Medicus Veterinus, 2(4), 453-460.

Ditjen PKH. (2019). Statistik Peternakan dan Kesehatan Hewan 2019. Jakarta, Indonesia: Kementerian Pertanian.

Fakhouri, F. M., Martelli, S. M., Caon, T., Velasco, J. I., \& Mei, L. H. I. (2015). Edible films and coatings based on starch/gelatin: Film properties and effect of coatings on quality of refrigerated Red Crimson grapes. Postharvest Biology and Technology, 109, 57-64. https://doi.org/10.1016/j. postharvbio.2015.05.015

Hatmi, R. U., Apriyati, E., \& Cahyaningrum, N. (2020). Edible coating quality with three types of starch and sorbitol plasticizer. E3S Web of Conferences, 142, 02003. https://doi.org/10.1051/ e3sconf $/ 202014202003$

JSA (Japanese Standards Association). (1975). JISZ-1707 General rules of plastic films for food packaging. Tokyo, Jepang: JSA.

Li, C., Pei, J., Zhu, S., Song, Y., Xiong, X., \& Xue, F. (2020). Development of chitosan/peptide films: Physical, antibacterial and antioxidant properties. Coatings, 10(12), 1193. https://doi.org/10.3390/ coatings10121193

Lindriati, T., Herlina, Nafi, A., \& Praptiningsih, Y. (2017). Prediction of carbohydrate-protein interaction in cassava starch-casein blended edible films. Advance Journal of Food Science and Technology, 13(7), 272-278. https://doi. org/10.19026/ajfst.13.5280

Lindriati, T., Praptiningsih, Y., \& Wijayanti, D. F. (2014). Physical characteristics of edible film gel made under various $\mathrm{pH}$ and ratio of casein and tapioca. Jurnal Ilmu Dasar, 15(1), 51-58. https:// doi.org/10.19184/jid.v15i1.614

Lisitsyn, A., Semenova, A., Nasonova, V., Polishchuk, E., Revutskaya, N., Kozyrev, I., \& Kotenkova, E. (2021). Approaches in animal proteins and natural polysaccharides application for food packaging: Edible film production and quality estimation. Polymers, 13(10), 1592. https://doi.org/10.3390/ polym 13101592

Maruddin, F., Ako, A., Hajrawati, \& Taufik, M. (2017). Karakteristik edible film berbahan whey dan kasein yang menggunakan jenis plasticizer berbeda. Jurnal Ilmu dan Teknologi Peternakan, 5(2), 97-101.

Martins, Y. A. A., Ferreira, S. V., Silva, N. M., Sandre, M. F. B., Filho, J. G. O., Leão, P. V. T., Leão, M, K., Nicolau, E. S., Plácido, G. R., Egea, M., B., \& da Silva, M. A. P. (2020). Edible films of whey and cassava starch: Physical, thermal, and microstructural characterization. Coatings, 10(11), 1059. https://doi.org/10.3390/coatings10111059

Mulyono, N., Suhartono, M. T., \& Angelina, S. (2015). Development of bioplastic based on cassava flour and its starch derivatives for food packaging. Journal of Harmonized Research in Applied Sciences, 3(2), 125-132.

Murti, T. W., Rihastuti, \& Purnomo, Y. A. (2011). Kajian kualitas fisik, kimia dan sensoris susu pasteurisasi pada pasteurizer berbeda. Prosiding Seminas Competitive Advantage, 1(1), 1-6.

Nurhajati, D. W. (2017). Pembuatan plastik biodegradabel untuk sarung tangan sekali pakai (1 tahun) (Laporan Penelitian). Yogyakarta, Indonesia: Balai Besar Kulit, Karet dan Plastik.

Nurhajati, D. W., Pidhatika, B., \& Harjanto, S. (2019). Biodegradable plastics from linier low-density polyethylene and polysaccharide: The influence of polysaccharide and acetic acid. Majalah Kulit, Karet, dan Plastik, 35(1), 33-40. https://doi. org/10.20543/mkkp.v35i1.4874

Nuriyah, L., Saroja, G., Ghufron, M., Razanata, A., \& Rosid, N. F. (2018). Karakteristik kuat tarik dan elongasi bioplastik berbahan pati ubi jalar cilembu dengan variasi jenis pemlastis. Natural $B, 4(4), 177-182$.

O’Chiu, E., \& Vardhanabhuti, B. (2017). Utilizing whey protein isolate and polysaccharide complexes to stabilize aerated dairy gels. Journal of Dairy Science, 100(5), 3404-3412. https://doi. org/10.3168/jds.2016-12053

Pellá, M. C. G., Silva, O. A., Pellá, M. G., Beneton, A. G., Caetano, J., Simões, M. R., \& Dragunski, D. C. (2020). Effect of gelatin and casein additions on 
starch edible biodegradable films for fruit surface coating. Food Chemistry, 309, 125764. https:// doi.org/10.1016/j.foodchem.2019.125764

Purnomo, H., \& Syamsul, E. S. (2017). Statistika farmasi (aplikasi praktis dengan SPSS). Yogyakarta, Indonesia: Grafika Indah.

Rahmawati, A. S., \& Erina, R. (2020). Rancangan acak lengkap (RAL) dengan uji anova dua jalur. Optika, 4(1), 54-62. https://doi.org/10.37478/ optika.v4i1.333

Rai, S., \& Poonia, A. (2019). Formulation and characterization of edible films from pea starch and casein. Journal of Pharmacognosy and Phytochemistry, 8(2), 317-321.

Riquelme, N., Díaz-Calderón, P., Enrione, J., \& Matiacevich, S. (2015). Effect of physical state of gelatin-plasticizer based films on to the occurrence of Maillard reactions. Food Chemistry, 175, 478-484. https://doi.org/10.1016/j. foodchem.2014.12.008

Romuli, S., Abass, A., \& Müller, J. (2017). Physical properties of cassava grits before and after pneumatic drying. Journal of Food Process Engineering, 40(2), e12397. https://doi. org/10.1111/jfpe. 12397

Ryder, K., Ali, M. A., Billakanti, J., \& Carne, A. (2020). Evaluation of dairy co-product containing composite solutions for the formation of bioplastic films. Journal of Polymers and the Environment, 28, 725-736. https://doi.org/10.1007/s10924-019$01635-4$

Sabil, S., Maruddin, F., Wahyuni, T., \& Taufik, M. (2021). Edible film characteristics at different casein concentrations. IOP Conference Series: Earth and Environmental Science, 788, 012115. https://doi.org/10.1088/1755-1315/788/1/012115

Saikia, M., \& Badwaik, L. S. (2018). Characterization and antimicrobial property of casein, gelatin and pectin based active composite films. Journal of Packaging Technology and Research, 2, 233-242. https://doi.org/10.1007/s41783-018-0044-3

Sarode, A. R., Sawale, P. D., Khedkar, C. D., Kalyankar, S.D., \& Pawshe, R.D.(2016). Casein and caseinate: Methods of manufacture. In B. Caballero, P. M. Finglas, F. Toldrá, (Eds.), Encyclopedia of Food and Health ( $1^{\text {st }}$ ed., pp. 676-682). London, UK: Oxford Academic Press. https://doi.org/10.1016/ B978-0-12-384947-2.00122-7

Skurtys, O., Acevedo, C., Pedreschi, F., Enronoe, J., Osorio, F., \& Aguilera, J. M. (2011). Food hydrocolloid edible films and coatings. New York, USA: Nova Science Publishers.
Socaciu, M., Fogarasi, M., Semeniuc, C. A., Socaci, S. A., Rotar, M.A., Mureşan, V., Pop, O. L., \& Vodnar, D. C. (2020). Formulation and characterization of antimicrobial edible films based on whey protein isolate and tarragon essential oil. Polymers, 12(8), 1748. https://doi.org/10.3390/POLYM12081748

Sucipta, I. N., Suriasih, K., \& Kenacana, P. K. D. (2017). Pengemasan pangan: Kajian pengemasan yang aman, nyaman, efektif dan efisien. Denpasar, Indonesia: Udayana University Press.

Suderman, N., Isa, M. I. N., \& Sarbon, N. M. (2018). The effect of plasticizers on the functional properties of biodegradable gelatin-based film: A review. Food Bioscience, 24, 111-119. https://doi. org/10.1016/j.fbio.2018.06.006

Thakur, V. K., Thakur, M. K., \& Kessler, M. R. (2017). Soy-based bioplastics. Shropshire, UK: Smithers Rappa.

Durmaz, B. U., \& Aytac, A. (2019). Poly (vinyl alcohol) and casein films: The effects of glycerol amount on the properties of films. Research on Engineering Structures \& Materials, 5(2), 155-165. https:// doi.org/10.17515/resm2018.62is0803

Vieira, M. G. A., da Silva, M. A., dos Santos, L. O., \& Beppu, M. M. (2011). Natural-based plasticizers and biopolymer films: A review. European Polymer Journal, 47(3), 254-263. https://doi. org/10.1016/j.eurpolymj.2010.12.011

Warkoyo, Rahardjo, B., Marseno, D. W., \& Karyadi, J. N. W. (2014). Sifat fisik, mekanik dan barrier edible film berbasis pati umbi kimpul (Xanthosoma sagittifolium) yang diinkorporasi dengan kalium sorbat. Agritech, 34(1), 72-81.

Wusigale, Liang, L., \& Luo, Y. (2020). Casein and pectin: Structures, interactions, and applications. Trends in Food Science \& Technology, 97, 391403. https://doi.org/10.1016/j.tifs.2020.01.027

Xiao, Y., Luo, H., Tang, R., \& Hou, J. (2021). Preparation and applications of electrospun optically transparent fibrous membrane. Polymers, 13(4), 506. https://doi.org/10.3390/polym13040506

$\mathrm{Xu}$, J., \& Gowen, A. A. (2019). Investigation of plasticizer aggregation problem in casein based biopolymer using chemical imaging. Talanta, 193, 128-138. $\quad$ https://doi.org/10.1016/j. talanta.2018.09.094

Yuwanti, S., Raharjo, S., Hastuti, P., \& Supriyadi. (2012). Mikroemulsi minyak dalam air (o/w) sebagai pembawa $\alpha$-tokoferol untuk menghambat sunlight flavor pada susu akibat fotooksidasi. Agritech, 32(2), 179-185. 
